\title{
Erratum: Transcriptomes of parents identify parenting strategies and sexual conflict in a subsocial beetle
}

\author{
Darren J. Parker, Christopher B. Cunningham, Craig A. Walling, Clare E. Stamper, Megan L. Head, \\ Eileen M. Roy-Zokan, Elizabeth C. McKinney, Michael G. Ritchie \& Allen J. Moore
}

Nature Communications 6:8449 doi: 10.1038/ncomms9449 (2015); Published 29 Sep 2015; Updated 27 May 2016

In the Methods section of this Article, a detail of the analysis involved in producing Fig. 4 and Table 2 was omitted. The section 'Mapping and detection of differential expression' should state that the overall magnitude of gene expression change was examined, ignoring the direction (up or downregulation). There are also errors in the labelling of axes in Fig. 6a. The $y$ axis of the graph on the left should have read ' $\log _{2}$-fold change of expression in biparental females' and the $x$ axis of the graph on the right should have read ' $\log _{2}$-fold change of expression in uniparental males'. The correct version of Fig. 6 appears below.
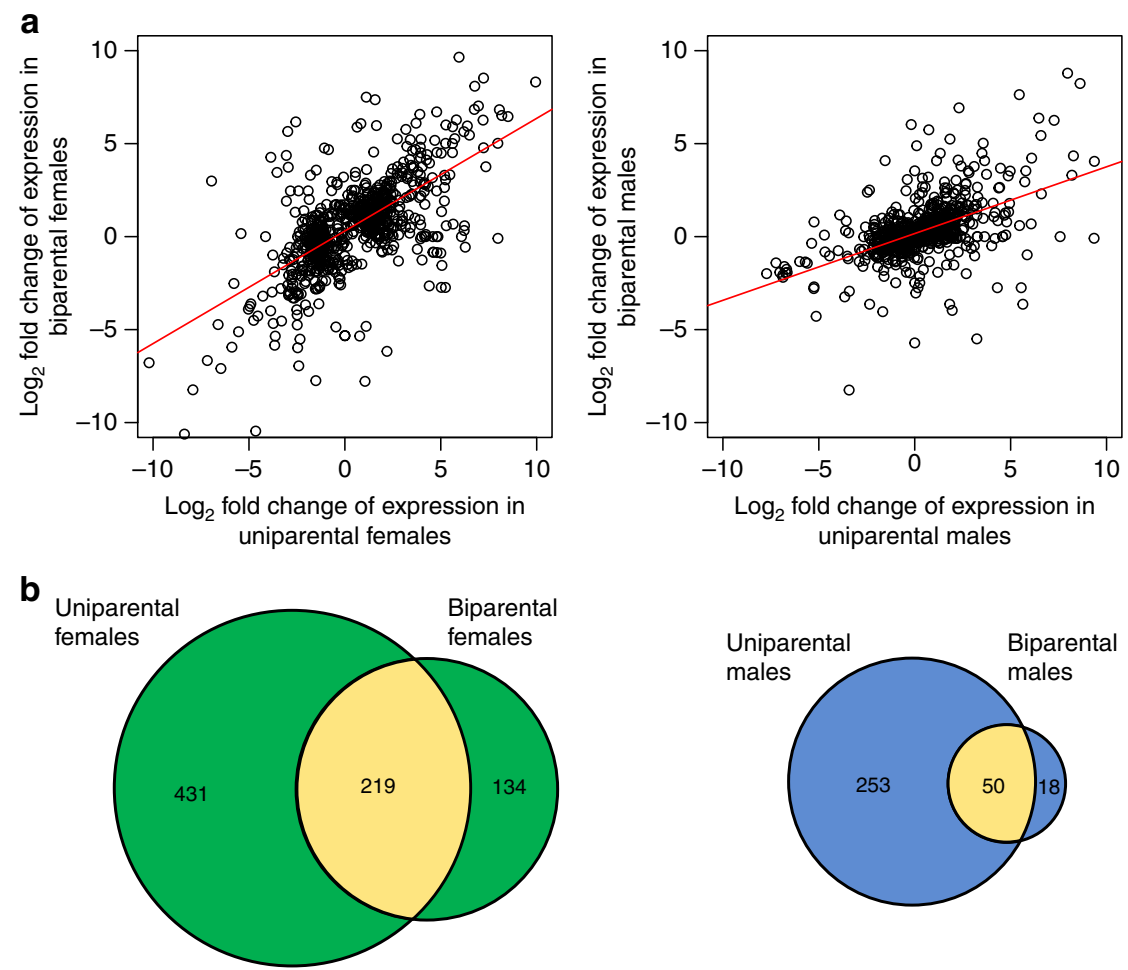

Figure 6

cc This work is licensed under a Creative Commons Attribution 4.0 International License. The images or other third party material in this article are included in the article's Creative Commons license, unless indicated otherwise in the credit line; if the material is not included under the Creative Commons license, users will need to obtain permission from the license holder to reproduce the material. To view a copy of this license, visit http://creativecommons.org/licenses/by/4.0/ 